\title{
Plasma cell mucositis - a rare differential diagnosis for ulceration of oral mucosa
}

\author{
Plazmocytarne zapalenie błon śluzowych - rzadka diagnostyka różnicowa zmian \\ w obrębie błon śluzowych jamy ustnej
}

Izabela Błażewicz, Wioletta Barańska-Rybak, Marta Stawczyk-Macieja, Andriy Petranyuk, Roman Nowicki

Department of Dermatology, Venereology and Allergology, Medical University of Gdansk, Gdansk, Poland

Przegl Dermatol 2015, 102, 520-523

DOI: 10.5 | | 4/dr.2015.55699

\section{KEY WORDS:}

mucous membrane

plasmacytosis, plasma cell gingivitis, erosions of the oral cavity.

\section{SŁOWA KLUCZOWE:}

plazmocytarne zapalenie błon śluzowych, plazmocytarne zapalenie dziąseł, nadżerki w obrębie jamy ustnej.

\section{ADDRESS FOR CORRESPONDENCE:}

Izabela Błażewicz

Department of Dermatology,

Venereology and Allergology

Medical University of Gdansk

7 Dębinki St

80-211 Gdansk

phone: +48 791002315

e-mail: izabela.blazewicz@wp.pl

\section{ABSTRACT}

Introduction. Plasma cell mucositis (PCM) is a rare condition consisting of plasma cell infiltrate of the mucous membranes that usually involves the genital epithelium. Less frequently lesions are present in the mouth or upper respiratory tract. The etiology of PCM remains unknown. The lesions may occur in the unchanged epithelium (idiopathic, isolated PCM), on the base of inflammatory skin diseases (lichen planus, lichen sclerosus) or cancer (squamous cell carcinoma).

Objective. To present a case and draw attention to PCM as a differential diagnosis of lesions within the oral mucous membrane.

Case report. We present a patient with painful erosions and erythematous patches located within the mucous membrane of the palate and cheeks lasting more than 5 months. The diagnosis was based on clinical and histopathological examination.

Conclusions. The course of PCM includes periods of exacerbations and remissions. Treatment with antibiotics, antifungal agents, local and systemic corticosteroids, isotretinoin or destructive methods usually provides symptomatic relief but does not lead to lesions regression.

\section{STRESZCZENIE}

Wprowadzenie. Plazmocytowe zapalenie błon śluzowych (ang. plasma cell mucositis - PCM) jest rzadką jednostką chorobową charakteryzującą się naciekiem plazmocytarnym, najczęściej obejmującym nabłonek zewnętrznych narządów płciowych. Znacznie rzadziej zmiany lokalizują się w obrębie jamy ustnej i górnych dróg oddechowych. Etiologia PCM jest nieznana. Zmiany mogą powstać w nabłonku niezmienionym (idiopatyczne, izolowane PCM), jak również na podłożu innych dermatoz zapalnych (liszaj płaski, liszaj twardzinowy) bądź chorób nowotworowych (rak kolczystokomórkowy).

Cel pracy. Przedstawienie przypadku PCM i zwrócenie uwagi na konieczność uwzględniania tej jednostki chorobowej w diagnostyce różnicowej zmian zlokalizowanych w obrębie błon śluzowych jamy ustnej. Opis przypadku. Prezentujemy przypadek pacjentki ze zmianami w obrębie błon śluzowych policzków i podniebienia w postaci nawracających od 5 miesięcy nadżerek, zmian rumieniowych i ognisk zbielenia z towarzyszącą bolesnością. Rozpoznanie choroby ustalono na podstawie obrazu klinicznego i wyniku badania histopatologicznego. 
Wnioski. Leczenie zmian z użyciem antybiotyków, leków przeciwgrzybiczych, glikokortykosteroidów miejscowych i systemowych, izotretynoiny lub metod destrukcyjnych przynosi zwykle krótkotrwałą poprawę.

\section{INTRODUCTION}

Plasma cell mucositis (PCM) is a rare, benign, idiopathic condition of the mucous membranes, which can involve the genital epithelium, oral cavity and upper respiratory tract. Zoon was the first to describe infiltration of mucous membranes by plasma cells [1]. In 1952 this reported condition was named 'chronic circumscribed benign balanoposthitis with plasmacytes'. The lesions in all of the described cases were localized on the glans penis. So far plasmacytic infiltration of mucous membranes has been presented under various names related to the area where accumulation of plasma cells was found. In the stomatological literature there are many descriptions of cases with changes located on gingiva reported as atypical gingivostomatitis [2], idiopathic gingivostomatitis [3] or allergic gingivostomatitis [4]. These cases are considered as a part of the spectrum of plasma cell orificial mucositis. In 1960, Schuermann proposed the designation 'plasmacytosis circumorificialis' to standardize the nomenclature [5]. Finally in 1986, White et al. suggested the term 'plasma-cell orificial mucositis' [6].

\section{OBJECTIVE}

To present a case of PCM and draw attention to PCM as a differential diagnosis of erosions and ulcerations of the oral mucous membrane.

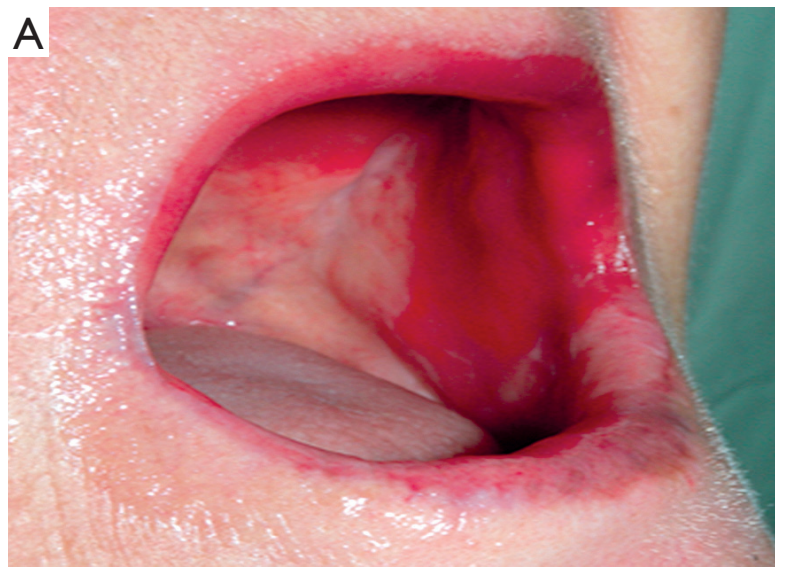

Figure I A, B. Clinical appearance before treatment

Rycina I A, B. Obraz kliniczny przed leczeniem

\section{CASE REPORT}

A 74-year-old woman, who suffered from arterial hypertension, diabetes type 2 and coronary heart disease, was admitted to the Dermatology Department due to erosions located on the mucous membranes of the oral cavity associated with chronic pain, difficulty with swallowing and mouth opening. The lesions appeared 5 months prior to hospitalization and according to the patient were connected with tooth extraction. The patient denied using chewing gum, herbal toothpaste or strong spices. The changes had been treated previously with topical antifungal agents, topical corticosteroid and topical and oral antibiotics without improvement.

Examination revealed swollen gingiva and lips. On the palate and the inner surface of the cheeks erosions and erythematous and edematous faintly demarcated lesions not bleeding on provocation were present (Figure 1). The changes were tender on palpation.

The differential diagnosis included pemphigus vulgaris, cicatricial pemphigoid, lichen planus, fungal infection and contact dermatitis. Pemphigus and pemphigoid antibodies as well as antinuclear antibodies were negative. Absence of fungal hyphae on microscopic examination and no growth on culture excluded fungal infection. Serum protein electrophoresis was within normal limits. Patch tests with contact allergens were performed, but they did not iden-

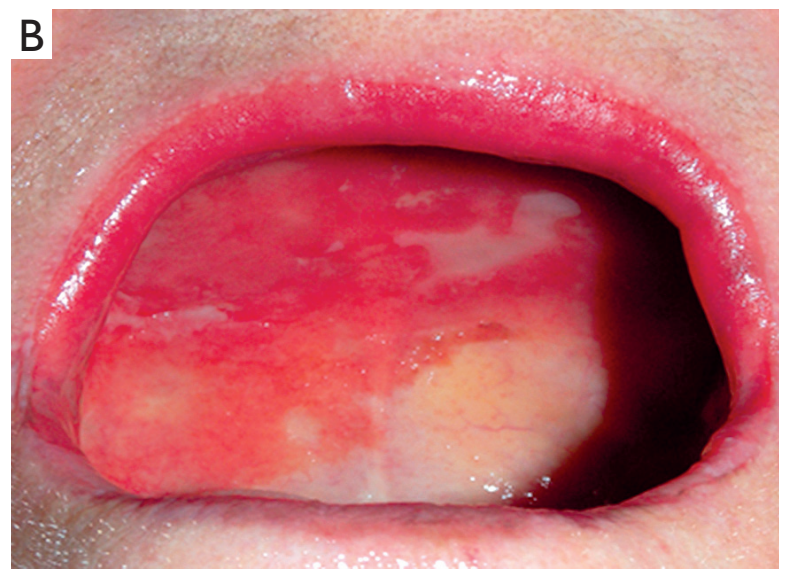




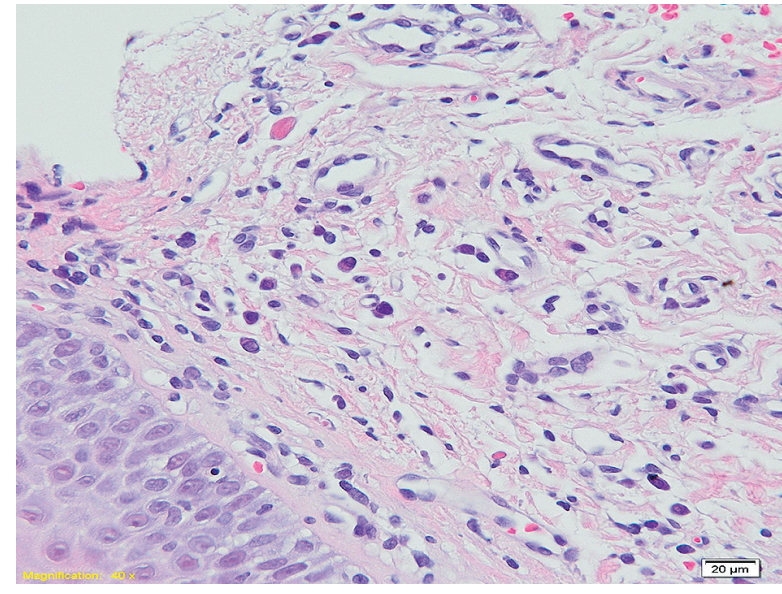

Figure 2. Histopathological examination: plasma cell infiltration without cellular atypia

Rycina 2. Obraz histopatologiczny - nacieki plazmocytowe bez atypii

tify potential allergens. The biopsy was taken from the buccal mucosa. The direct immunofluorescence examination was negative. Histopathologic examination revealed plasma cell infiltrate with no cellular atypia. There was no histopathological evidence of blistering disease, lichen planus or chronic ulcerative stomatitis (Figure 2). The diagnosis of plasma cell orificial mucositis was established based on clinical and histopathological data and also on the exclusion of other diseases. The patient was treated with oral corticosteroids (prednisone in an initial dose of $40 \mathrm{mg}$ /day), which provided relief. Unfortunately, while reducing the dose the lesions regressed. Based on literature reports, during the next hospitalizations the patient was treated with methylprednisolone ( 3 i.v. infusions in a dose of $0.5 \mathrm{~g}$, a total dose of $1.5 \mathrm{~g}$ ), but due to side effects (Cushing's syndrome and atrial fibrillation requiring cardioversion) we decided to discontinue this therapy. Presently the patient is still undergoing treatment with oral prednisone in a dose of $15 \mathrm{mg} /$ day and tacrolimus $0.1 \%$ ointment with partial recovery.

\section{DISCUSSION}

Plasma cell mucositis is a rare condition with less than 50 cases reported. The origin of the disease is unknown. The lesions may occur in the unchanged epithelium (idiopathic, isolated PCM) [7] as well as on the base of inflammatory skin diseases (lichen planus, lichen sclerosus) or epidermal neoplasia (Bowen disease, squamous cell carcinoma) [8]. In many cases patients with PCM also had a history of autoimmune diseases such as rheumatoid arthritis, diabetes, Sjogren syndrome and autoimmune hepatitis [9]. Our patient did not suffer from any autoimmune disease.

The clinical picture of the disease varies and is connected with localization of lesions. In the pre- sent case, swollen lips and gums were observed. The mucous membranes are intensely erythematous with the surface described as cobblestone, wart-like, nodular or papillomatous $[9,10]$. The most frequent symptoms include oral pain, difficulty with swallowing, mouth opening and persistent hoarseness. When lesions are localized on the larynx and trachea, dysphonia may occur. The above-mentioned symptoms except dysphonia were present in our patient.

Plasma cell mucositis is a diagnosis of exclusion based mainly on histopathological examination. The differential diagnosis of plasma-cell orificial mucositis includes allergic or contact mucositis, pemphigus vulgaris, cicatricial pemphigoid, lichen planus, fungal infection, plasmoacanthoma and syphilis [11]. To exclude most of those diseases many diagnostic tests, as in the reported case, should be performed: mycological examination, serologic tests for syphilis, patch tests, histopathological and direct immunofluorescence (DIF) examinations, serum protein electrophoresis, pemphigus and pemphigoid antibodies as well as antinuclear antibodies.

In our case absence of fungal hyphae on microscopic examination, no growth on culture and no response to treatment with antifungal agents excluded fungal infection. The suspicion of blistering diseases was not confirmed. In histopathological and DIF examinations there was no evidence of pemphigus or pemphigoid. Also pemphigus and pemphigoid antibodies were negative. We excluded allergic and contact dermatitis. Patch tests did not identify any allergen.

Microscopically in PCM, a dense subepithelial infiltrate of plasma cells is described. In many cases, plasma cells are not predominant in the infiltrate. The presence of other inflammatory cells, especially leukocytes and lymphocytes, is common. Also Russell bodies (immunoglobulin within cytoplasm of plasma cells) can be occasionally noted [11, 12]. The histopathological picture of PCM can mimic many diseases such as multiple myeloma, extramedullary plasmacytoma (EXM), or Waldenstrom's macroglobulinemia. In both PCM and EXM there is a diffuse infiltrate of plasma cells in the dermis and subcutaneous tissues. Tissue biopsy showing monoclonal plasma cell histology and presence of atypical plasma cells may arouse the suspicion of extramedullary plasmacytoma. Plasma cell mucositis should also be distinguished from plasma cell gingivitis. Plasma cell gingivitis is a rare, benign condition, which is thought to be a hypersensitivity response. Many authors claim that it is an immunological reaction to allergens present in toothpaste, mint pastels, chewing gum, khat, food flavoring allergens and oral care products [13-15]. Our patient used dentures, but removal of them did not result in improvement. 
Treatment of PCM is based mainly on relieving symptoms. Many methods of treatment have been reported, including topical [13] systemic [10] and intralesional $[6,14]$ corticosteroids, and pulses of corticosteroids [9]. In some reported cases application of corticosteroids resulted in partial $[15,16]$ or complete $[13,17]$ regression. Antibiotics [16] and antifungals $[6,18]$ have also been used to treat PCM. Some of the authors also used destructive therapy: electrocoagulation, surgical excision $[12,18]$, carbon dioxide laser and cryotherapy [19]. Topical tacrolimus has been reported to have a beneficial effect in treatment of a plasma cell infiltration of the lower lip [20, 21]. In most of the reported cases treatment resulted in stabilization of disease without regression.

\section{CONCLUSIONS}

Mucous membrane plasmacytosis is a diagnosis of exclusion, distinguished primarily on the histopathologic finding of a marked submucosal plasma-cell infiltrate, after conditions such as infection and plasmacytoma have been eliminated. The best treatment for mucous membrane plasmacytosis is also unclear, with inconsistent data from trials with corticosteroids, antibiotics, radiation, ablative therapy, and surgical excision. The PCM should be taken into account in the differential diagnosis of erosions on the mucous membrane.

\section{Conflict of interest}

The authors declare no conflict of interest.

\section{References}

1. Zoon J.J.: Chronic benign circumscripta plasmacytic balanoposthitis. Dermatologica 1952, 105, 1-7.

2. Owings J.R.: An atypical gingivostomatitis: a report of four cases. J Periodontol 1969, 40, 5938-5942.

3. Perry H.O.: Idiopathic gingivostomatitis. Dermatol Clin 1987, 5, 719-722.

4. Regezi J.A., Taylor C.G., Spinelli F.R., Lucas R.N.: Allergic gingivostomatitis with laryngeal manifestations: report of case. J Oral Surg 1972, 30, 373-377.

5. Schuermann H.: Plasmacytosis circumorificialis. Dtscg Zahnarztl 1960, 15, 601-610.

Received: 12 V 2015

Accepted: 24 IX 2015
6. White J.W., Olsen K.D., Banks P.M.: Plasma cell orificialmucositis: report of a case and review of the literature. Arch Dermatol 1986, 122, 1321-1324.

7. Patanwala A., Fisher E.W., Chapple I.L.C.: Plasma cell gingivitis affecting the gingiva, palatal mucosa and laryngeal cords. Perio 2006, 3, 123-128.

8. Sollecito T.P., Greenberg M.S.: Plasma cell gingivitis: report of two cases. Oral Surg Oral Med Oral Pathol 1992, 73, 690-693.

9. Solomon L.W., Wein R.O., Rosenwald I., Laver N.: Plasma cell mucositis of the oral cavity: report of a case and review of the literature. Oral Surg Oral Med Oral Pathol Oral Radiol Endod 2008, 106, 853-860.

10. Ferreiro J.A., Egorshin E.V., Olsen K.D., Blanks P.M., Weiland L.H.: Mucous membrane plasmacytosis of the upper aerodigestive tract: a clinicopathologic study. Am J Surg Pathol 1994, 18, 1048-1053.

11. Bharti R., Smith D.R.: Mucous membrane plasmacytosis: a case report and review of the literature. Dermatol Online J 2003, 9, 15.

12. Shruthi S., Gujjari S.K., Hegde U., Kumar V.: Unusual clinical presentation of a case of localized plasma cell gingivitis. J Clin Diagn Res 2011, 5, 1125-1127.

13. Jones S.K., Kennedy C.T.: Response of plasma cell orificial mucositis to topically applied steroids. Arch Dermatol 1988, 124, 1871-1872.

14. Timms M.S., Sloan P.: Association of supraglottic and gingival idiopathic plasmacytosis. Oral Surg Oral Med Oral Pathol 1991, 71, 451-453.

15. Timms M.S., Sloan P., Balzan A.P.: Idiopathic plasmacytosis of the oral and supraglottic mucosa. J Laryngol Otol 1988, 102, 646-648.

16. Mahler V., Hornstein O.P., Kiesewatter F.: Plasma cell gingivitis: treatment with $2 \%$ fusidic acid. J Am Acad Dermatol 1996, 34, 145-146.

17. Khan N.A., McKerrow W.S., Palmer T.J.: Mucous membrane plasmacytosis of the upper aerodigestive tract. A case report with effective treatment. J Laryngol Otol 1997, 111, 293-295.

18. Puvanendran M., Lieder A., Issing W.: Plasma cell mucositis of oro-and hypopharynx: a case report. Case Report Otolaryngol 2012, 304136, doi: 10.1155/2012/304136. Epub 2012 Jun 17.

19. Najarian D.J., Rao B.K., Pappert A.S.: A case of mucous membrane plasmacytosis successfully treated with cryotherapy. Dermatol Online J 2008, 14, 6.

20. Jin S.P., Cho K.H., Huh C.H.: Plasma cell cheilitis, successfully treated with topical $0.03 \%$ tacrolimus ointment. J Dermatol Treat 2010, 21, 130-132.

21. Hanami Y., Motoki Y., Yamamoto T.: Successful treatment of plasma cell cheilitis with topical tacrolimus: report of two cases. Dermatol Online J 2011, 17, 6. 